\section{Evaluation of Twenty-one Mountain Laurel Cultivars for Container and Landscape Performance in the Southeastern United States}

\author{
He Li, Matthew Chappell, and Donglin Zhang ${ }^{1}$
}

AdDitional INDEX wORDs. Kalmia latifolia, growth index, morphology, performance rating, maximum quantum yield, stress tolerance

SUMMARY. Mountain laurel (Kalmia latifolia) is an outstanding ornamental shrub due to its attractive foliage and showy inflorescences. Breeding efforts have led to improved selections that have predominantly been developed and evaluated in the northeastern United States. Consequently, most cultivars have largely been dismissed as incompatible for the southeastern U.S. environmental conditions by nursery growers and consumers. This study was conducted over a 4-year period to evaluate 21 popular mountain laurel cultivars, primarily developed in the northeastern United States, for container and field performance in Georgia. All cultivars yielded considerable growth in the first year of container trials, indicating production of mountain laurel as a 1-year container crop is feasible. Cultivars displayed significantly different total growth index throughout the container trial. Fastgrowing cultivars such as Bullseye and Ostbo Red yielded more than 100, 150, and $250 \mathrm{~cm}$ of growth index in 1, 2, and 4 years, respectively. Conversely, cultivars that grew slower, such as Firecracker and Tinkerbell, had less than 80,115 , and $180 \mathrm{~cm}$ in 1,2 , and 4 years, respectively. Cultivars were classified into five groups, using principal component analysis, that included dwarf habit with pink flower, dwarf habit with nonpink flower, nondwarf habit with green stem and white flower, nondwarf habit with pigment-patterned flower, and nondwarf habit with pink flower. In a field study, performance rating of 21 cultivars ranged from 2.0 to 4.8 (out of 5.0) in 2014 and from 2.0 to 5.0 in 2015. Ten cultivars that received the highest ratings over these 2 years were selected for a subsequent field trial in 2016 . Cultivars showed overall decreased ratings (1.0-3.3) from the previous 2 years because of late spring planting. 'Ostbo Red', 'Pristine', and 'Tinkerbell' had higher performance ratings, more net growth, and less decrease in maximum quantum yield, which indicated suitable adaptation to southeastern U.S. environmental conditions. Nursery growers and consumers should benefit from regional cultivar trial information derived from this study. 'Ostbo Red', 'Pristine', and 'Tinkerbell' performed well across trials and therefore are recommended for southeastern U.S. landscapes based on superior container and field performance, leaf spot (caused by Mycosphaevella colorata) tolerance, and morphologic distinctions.

$\mathrm{M}$ ountain laurel is an evergreen flowering shrub in the heath family (Ericaceae) that occurs throughout temperate areas of the world (Jaynes, 1988). Mountain laurel is native to the eastern United States, specifically from southern Maine west through southern New York to central Ohio, south to eastern Louisiana, southern Mississippi, Alabama, Georgia, and northwestern Florida (Kurmes, 1967). The plant has been considered by many horticulturists, nursery growers, and gardeners to be an outstanding flowering native species (Dirr, 2009; Jaynes, 1988). Its attractive, lustrous green

Department of Horticulture, University of Georgia, 1111 Miller Plant Sciences Building, Athens, GA 30602

${ }^{1}$ Corresponding author. E-mail: donglin@uga.edu.

https://doi.org/10.21273/HORTTECH04174-18 foliage; showy inflorescences; and variations in morphological traits have made mountain laurel a valuable ornamental shrub in the nursery and landscape industries (Jaynes, 1988).

Many cultivars of mountain laurel have been introduced into the marketplace, beginning in the early 1960s (European Kalmia Society, 2018). Yet there is still considerable uncertainty about these plants and their performance in areas south of U.S. Department of Agriculture
(USDA) Zone 7, particularly in the southeastern United States. In the southeastern United States, few cultivars are available in retail settings and those cultivars that are produced are principally done so by niche, heathfamily nurseries. Ironically, although produced in several southeastern U.S. nurseries, mountain laurel is rarely used in southeastern U.S. landscapes (Jaynes, 1988). The majority of mountain laurel cultivars were evaluated (before release) and selected for release in the northeastern United States. As a result, the performance of cultivars outside the northeastern United States is relatively unknown, which has historically limited cultivar acceptance in other regions of the United States (Jaynes, 1982, 1988). An example of this regionality in cultivar development and use is 'Sarah', selected by R.A. Jaynes at the Connecticut Agricultural Experiment Station. Although well adapted to northeastern U.S. landscapes, no documentation exists regarding its broader adaptability due to a lack of evaluation outside the northeastern United States.

Southeastern U.S. climate varies significantly from that of the Northeast. Milder winter temperatures lead to less cold damage in nurseries and landscapes of the southeastern United States. Yet hotter and more humid summer conditions, as well as a lack of winter chilling hours, could limit adaptability of cultivars selected in the Northeast and transitioned into southeastern U.S. nurseries and landscapes. Limited information on physiological and adaptive responses, including heat tolerance, photosynthetically active radiation tolerance, growth rates, disease and insect tolerance, required chilling hours to flower, soil moisture tolerance, for example, for most of mountain laurel cultivars is available (Jaynes, 1982, 1988). Additionally, although phenotypic traits of many mountain laurel cultivars have been well described at the time of release, these traits may differ across drastically different physiographic

\begin{tabular}{llll}
\hline $\begin{array}{l}\text { Units } \\
\text { To convert U.S. to SI, } \\
\text { multiply by }\end{array}$ & U.S. unit & SI unit & $\begin{array}{l}\text { To convert SI to U.S., } \\
\text { multiply by }\end{array}$ \\
\hline 0.3048 & $\mathrm{ft}$ & $\mathrm{m}$ & 3.2808 \\
3.7854 & gal & $\mathrm{L}$ & 0.2642 \\
2.54 & inch(es) & $\mathrm{cm}$ & 0.3937 \\
1.6093 & mile(s) & $\mathrm{km}$ & 0.6214 \\
28.3495 & $\mathrm{oz}$ & $\mathrm{g}$ & 0.0353
\end{tabular}


regions (Jaynes, 1988) due to genotype by environment interactions (Schlichting, 1986). This phenotypic variability was documented to occur in inkberry (Ilex glabra), whereby leaf traits varied when grown in varying environments (Givnish, 1984). This study evaluated 21 popular mountain laurel cultivars for their potential as both nursery and landscape plants. Our objectives were to provide comprehensive regional cultivar information for growers, landscape contractors, and breeders that could enhance mountain laurel production and landscape performance by identifying those cultivars with greatest adaptability to the southeastern United States.

\section{Materials and methods}

Plant materials. Liners of 21 cultivars were commercially micropropagated, rooted, and shipped from Briggs Nursery, Inc. (Elma, WA) to the University of Georgia Durham Horticulture Farm (UGA Hort Farm) in Watkinsville, GA [lat. $33.88689^{\circ} \mathrm{N}$, long. $83.41941^{\circ} \mathrm{W}$, $236 \mathrm{ft}$ elevation, USDA Zone 8a (USDA, 2012)] on 11 Mar. 2013 in 49-cell flats. These cultivars were selected based on their popularity, reported superior landscape performance, and their diversity in habit, foliage, and inflorescence in the northeastern United States (Fig. 1). Liners $(8-10 \mathrm{~cm}$ tall, 5-6 $\mathrm{cm}$ wide) were immediately transplanted into l-gal containers (PF310; Nursery Supplies, Chambersburg, PA) filled with pine bark-based soilless substrate (85\% bark pine, $15 \%$ compost; Sun Gro Horticulture, Agawam, MA). Potted plants were top-dressed with
$5 \mathrm{~g}$ of $20 \mathrm{~N}-1.3 \mathrm{P}-7.5 \mathrm{~K}$ controlledrelease fertilizer (Everris, Marysville, $\mathrm{OH})$. Containers were held in an unheated coldframe covered with $60 \%$ shadecloth and irrigated twice per day ( 15 min per irrigation event) using 10 -ft full-circle nozzles (Rain Bird, Azusa, CA) monitored by a timer (Node-100; Hunter, San Marcos, CA) until container and field trials were initiated.

Container evaluation. Container performance was assessed at the UGA Hort Farm beginning on 4 May 2013. On 21 May 2015, the plants were transplanted from 1- to 3-gal containers (PF1200; Nursery Supplies) filled with bark-based substrate as described previously and fertilized with $15 \mathrm{~g}$ of $20 \mathrm{~N}-$ 1.3P-7.5K controlled-release fertilizer (Everris). Plants were maintained in

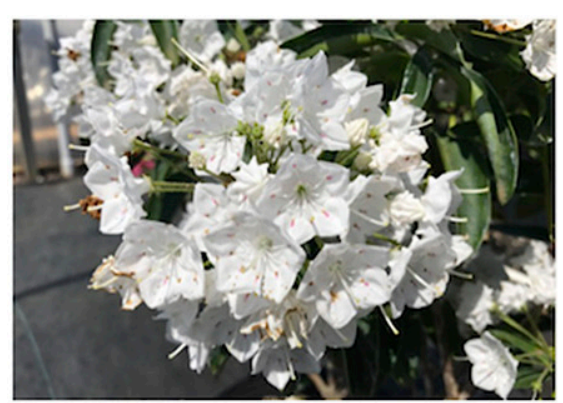

'Pristine'

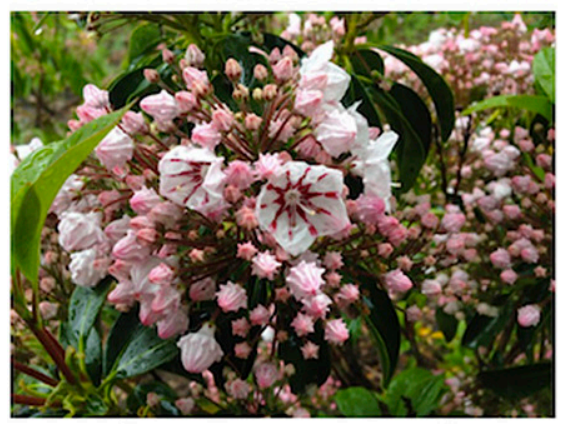

'Peppermint'

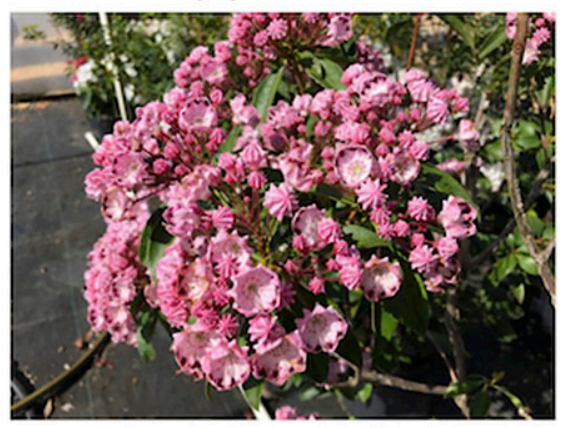

'Red Bandit'

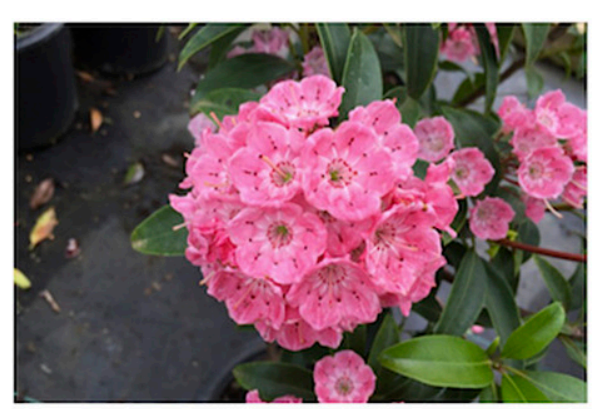

'Sarah'

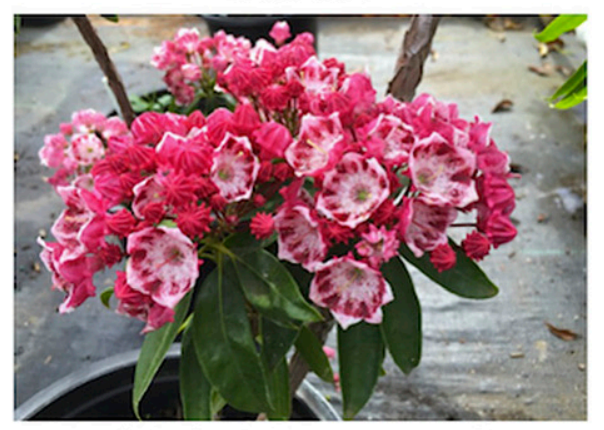

'Kaleidoscope'

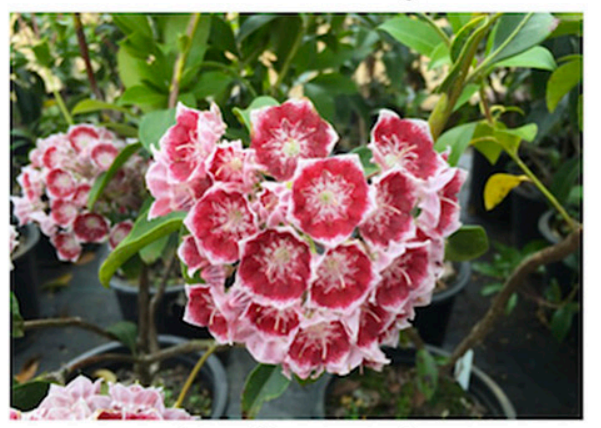

'Bullseye'

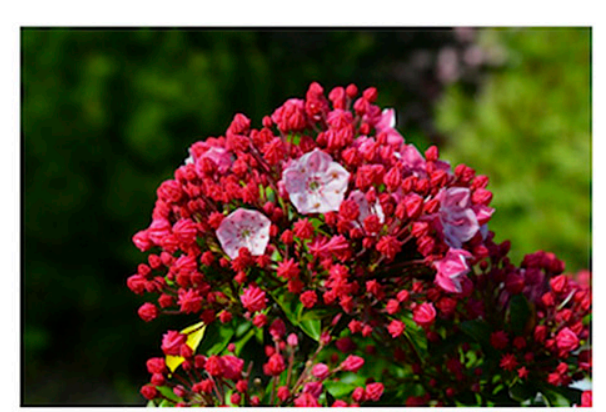

'Nathan Hale'

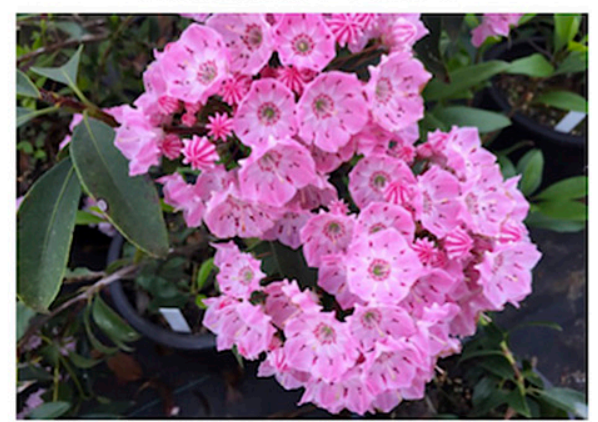

'Pink Charm'

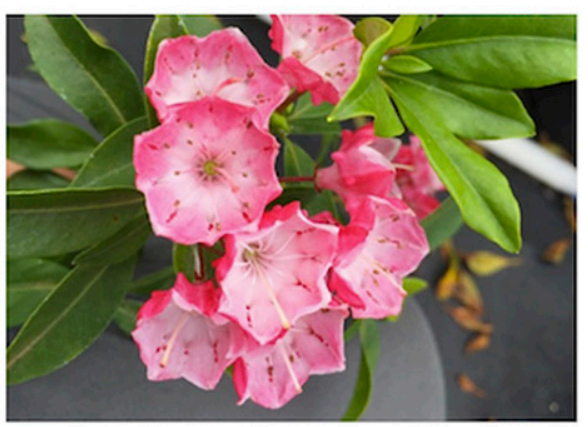

'Ostbo Red'

Fig. 1. Diversity in size, shape, color, and pigment pattern of flowers among popular mountain laurel cultivars. 
the same shade-house as described earlier for continued evaluation as 3gal containers through the end of the trial in 2017 and top-dressed with $20 \mathrm{~N}-1.3 \mathrm{P}-7.5 \mathrm{~K}$ controlled-release fertilizer (Everris) annually.

Total growth index measurements were taken in the first week of May 2014, 2015, and 2017. Measurements included height (ground level to the tallest point), width at the widest point, and width perpendicular to the widest point. Growth index was then calculated as height + width $1+$ width 2. Morphological traits were observed on container-grown plants throughout the container trial. Morphological measurements were taken on 11 traits that described habit, flowering, and leaf characteristics. Traits described by Jaynes (1988) that are responsible for major variations among cultivars were documented. These are described in Table 1 and included habit, stem and petiole color, leaf size, leaf blade, leaf surface, leaf color, flower size, bud color, corolla color, pigment pattern, and bloom time. Size measurements, including flower and leaf size, were taken on three flowers in full bloom and three mature leaves on each plant. Additionally, leaf spot incidence was recorded, but severity was not assessed.

Field trial. The first field trial was conducted at the UGA Hort Farm from 2013 to 2015 . Four 1gal containerized plants of the same 21 cultivars evaluated in containers were transplanted to the field on 1 Oct. 2013. The planting bed was tilled to a 10-inch depth before planting and existing Cecil clay soil (unamended) was used as backfill into planting holes. The trial was divided into four replications (rows), and one plant of each cultivar was randomly assigned to each replication. Plants were transplanted on 6-ft centers. The root balls were slightly split and then covered with backfill-soil. Plants were top-dressed with $15 \mathrm{~g}$ of $20 \mathrm{~N}$ 1.3P-7.5K controlled-release fertilizer (Everris), and then beds were mulched with a 2 -inch-thick layer of pine straw. Plants were watered using drip irrigation with emitters $[2 \mathrm{gal} / \mathrm{h}$ (XB20PC, Rain Bird)] immediately after planting and then watered as needed by manually turning on and off an irrigation valve. Plant performance rating was evaluated on 8 Oct. 2014 and 7 Oct. 2015. The performance rating was made using a scale of 1 (dead) to 5 (excellent: vigorous growth, lush and green foliage, no leaf spot, and no above-ground damage), based on overall plant size and vigor, leaf color, incidence of leaf spot, and leaf and shoot damage due to abiotic conditions.

On the basis of the results of 2014 and 2015 field trial, 2-year-old l-gal container plants of the highest rated 10 cultivars were planted in a field plot in the same manner as described earlier at the UGA Riverbend Research Center in Athens, GA [lat. $33.93014^{\circ} \mathrm{N}$, long. $83.36364^{\circ} \mathrm{W}$,
$670 \mathrm{ft}$ elevation, USDA Zone 8a (USDA, 2012)] on 14 Apr. 2016. Four replications were installed, each with one plant of each cultivar randomized within replication. Plants were installed in unamended Cecil clay field soil on 6 -ft centers within two cultivated rows tilled to a depth of 10 inches. Light energy absorbed by chlorophyll in a leaf undergoes three fates: being used to drive photosynthesis, being emitted as heat, and being reemitted as chlorophyll fluorescence. The spectrum of chlorophyll fluorescence is different from that of absorbed light. As a result, the yield of chlorophyll fluorescence can be measured and this information served as an indication of photosynthetic efficiency. Maximum quantum yield of photosystem II $\left(\mathrm{F}_{\mathrm{v}} / \mathrm{F}_{\mathrm{m}}\right)$ is calculated as $\left(\mathrm{F}_{\mathrm{m}}-\mathrm{F}_{0}\right) / \mathrm{F}_{\mathrm{m}}$, where $\mathrm{F}_{\mathrm{m}}$ and $\mathrm{F}_{0}$ indicate maximum and minimal level of fluorescence, respectively. $\mathrm{F}_{\mathrm{v}} / \mathrm{F}_{\mathrm{m}}$ has been used as a determination of damage to photosystem II due to abiotic (e.g., heat and light) stress (Baker and Rosenquist, 2004; Maxwell and Johnson, 2000). This study quantified decreases in $\mathrm{F}_{\mathrm{v}} / \mathrm{F}_{\mathrm{m}}$ over the course of a growing season to determine abiotic stress tolerance of cultivars in the 2016 field study. $\mathrm{F}_{\mathrm{v}} / \mathrm{F}_{\mathrm{m}}$ was measured on three leaves of each plant beginning at dawn and ending at sunrise using a portable fluorometer (FluorPen FP 100; Photon Systems Instruments, Albuquerque, NM). Baseline $\mathrm{F}_{\mathrm{v}} / \mathrm{F}_{\mathrm{m}}$ and growth index were recorded while plants were in

Table 1. Eleven morphologic characters describing habit, flowering, and leaf characteristics observed on 21 mountain laurel cultivars for morphological measurements.

\begin{tabular}{|c|c|c|c|c|c|}
\hline \multirow[b]{2}{*}{ Character } & \multicolumn{5}{|c|}{ Numerical description $^{\mathrm{z}}$} \\
\hline & 0 & 1 & 2 & 3 & 4 \\
\hline Habit & Sparse and dwarf & Dense and dwarf & Sparse and typical & Dense and typical & \\
\hline $\begin{array}{l}\text { Stem and petiole } \\
\text { color }\end{array}$ & Green & Slightly purplish red & $\begin{array}{l}\text { Moderately purplish } \\
\text { red }\end{array}$ & Purplish red & \\
\hline Leaf size & $\begin{array}{l}\text { Length + width } \\
\quad<5 \mathrm{~cm}\end{array}$ & $\begin{array}{l}5 \mathrm{~cm}<\text { length + width } \\
\quad<8 \mathrm{~cm}\end{array}$ & Length + width $>8 \mathrm{~cm}$ & & \\
\hline Leaf blade & Elliptic & Elliptic to ovate & Elliptic to lanceolate & Lanceolate & $\begin{array}{r}\text { Lanceolate } \\
\text { to ovate }\end{array}$ \\
\hline Leaf surface & Flat & V-shaped & Cupped & Wavy & \\
\hline Leaf color & Medium green & Medium to dark green & Dark green & & \\
\hline Flower size & Diameter $<1.8 \mathrm{~cm}$ & $\begin{array}{l}1.8 \mathrm{~cm}<\text { diameter } \\
\quad<2.5 \mathrm{~cm}\end{array}$ & Diameter $>2.5 \mathrm{~cm}$ & & \\
\hline Bud color & White & Light pink & Pink & Deep pink & Red \\
\hline Corolla color & White & Light pink & Pink & Deep pink & \\
\hline Pigment pattern & No pigment & Normal band & Full band & Radiation & Spot \\
\hline Bloom time & Before 1 May & Between 1 and 15 May & After 15 May & & \\
\hline
\end{tabular}

${ }^{\mathrm{z}}$ Size measurements, including leaf and flower size, were taken on three mature leaves and three flowers in full bloom on each plant; $1 \mathrm{~cm}=0.3937$ inch. 
containers, the day before cultivars were planted (13 Apr. 2016). Final growth index and $\mathrm{F}_{\mathrm{v}} / \mathrm{F}_{\mathrm{m}}$ were measured on plants in field plots on 9 Nov. 2016. Net growth was then calculated as final growth index - initial growth index. The percentage of decrease in $\mathrm{F}_{\mathrm{v}} / \mathrm{F}_{\mathrm{m}}$ was calculated as [(initial $\mathrm{F}_{\mathrm{v}} / \mathrm{F}_{\mathrm{m}}-$ final $\left.\mathrm{F}_{\mathrm{v}} / \mathrm{F}_{\mathrm{m}}\right) /$ initial $\left.\mathrm{F}_{\mathrm{v}} / \mathrm{F}_{\mathrm{m}} \times 100 \%\right]$. Plant performance ratings were collected using the same 1 to 5 scale as described in the first field trial.

EXPERIMENTAL DESIGN AND DATA ANALYsIs. Experimental design for the container evaluation study was a completely randomized design with four replications. Each replication included one plant of 21 cultivars. Likewise, randomized complete block design was employed for the field trial, which included four replications with one plant of each cultivar per replication. Growth index, net growth, performance rating, and the percentage change in $\mathrm{F}_{\mathrm{v}} / \mathrm{F}_{\mathrm{m}}$ were subjected to analysis of variance using GLM procedures in SAS (University Edition; SAS Institute, Cary, NC). Fisher's least significant difference at $P<0.05$ was applied for mean separation. Principal component analysis (PCA) was performed on morphological traits using SPSS (version 21.0; IBM Crop, Armonk, NY). The first two axes were plotted according to the extracted Eigen vectors in Excel (Microsoft, Redmond, WA).

\section{Results and discussion}

Container evaluation. Twentyone container-grown mountain laurel cultivars reached $60 \mathrm{~cm}$ or greater total growth in the first year (201314). At this size, plants would be marketable after a $\mathrm{l}$-year production cycle, indicating it is feasible to commercially produce mountain laurel as container plants in the southeastern United States. Yet cultivars displayed differences in plant size during container evaluation (Table 2). In 2014, 'Bullseye', 'Forever Red', 'Freckles', 'Heart of Fire', 'Olympic Fire', 'Ostbo Red', and 'Pink Charm' had growth indices of $\geq 100 \mathrm{~cm}$ (Table 3). These large cultivars continued vigorous growth rates in containers after 2 years of production in $2015(\geq 145 \mathrm{~cm})$ and 4 years of production in $2017(\geq 230 \mathrm{~cm})$. 'Carol' and 'Peppermint' showed similar

Table 2. Analysis of variance table for growth index of 21 mountain laurel cultivars in container evaluation; performance rating of 21 cultivars in 2014 and 2015 field trial; and performance rating, net growth, and decrease in $F_{v} / F_{m}$ of 10 cultivars in 2016 field trial. ${ }^{z}$

\begin{tabular}{lllll}
\hline Source & df & Mean square & F & $P$ \\
\hline
\end{tabular}

Container evaluation

Cultivar

2014 growth index

2015 growth index

2017 growth index

$\begin{array}{cccc}20 & 622.8 & 7.1 & <0.0001 \\ 20 & 2,277.7 & 7.1 & <0.0001 \\ 20 & 5,929.3 & 9.3 & <0.0001 \\ 2014 \text { and } 2015 \text { Field trial } & & \end{array}$

Cultivar

2014 performance rating

2015 performance rating

$\begin{array}{llll}20 & 2.5 & 1.83 & 0.0380 \\ 20 & 3.1 & 1.2 & 0.2987\end{array}$

Cultivar

Performance rating

Net growth

Decrease in $\mathrm{F}_{\mathrm{v}} / \mathrm{F}_{\mathrm{m}}(\%)$

2016 Field trial

${ }^{2} \mathrm{~F}_{\mathrm{v}} / \mathrm{F}_{\mathrm{m}}=$ maximum quantum yield. Decrease in $\mathrm{F}_{\mathrm{v}} / \mathrm{F}_{\mathrm{m}}$ was calculated as $\left[\left(\right.\right.$ initial $\mathrm{F}_{\mathrm{v}} / \mathrm{F}_{\mathrm{m}}-$ final $\left.\mathrm{F}_{\mathrm{v}} / \mathrm{F}_{\mathrm{m}}\right) /$ initial $\left.\mathrm{F}_{\mathrm{v}} / \mathrm{F}_{\mathrm{m}} \times 100 \%\right]$

Table 3. Growth index of container-grown plants of 21 mountain laurel cultivars at the University of Georgia Durham Horticulture Farm in Watkinsville, GA, after being grown for 1 (2014), $2(2015)$, and 4 years $(2017)(n=4)$.

\begin{tabular}{lccc}
\hline & \multicolumn{3}{c}{ Growth index $[\text { mean } \pm \text { SE }(\mathrm{cm})]^{\mathrm{z}}$} \\
\cline { 2 - 4 } Cultivar & $\mathbf{2 0 1 4}$ & $\mathbf{2 0 1 5 ^ { \mathrm { y } }}$ & $\mathbf{2 0 1 7}$ \\
\hline Bullseye & $100.1 \pm 9.3 \mathrm{ab}^{\mathrm{x}}$ & $158.5 \pm 12.4 \mathrm{abcde}$ & $301.2 \pm 12.2 \mathrm{a}$ \\
Carol & $86.4 \pm 3.4 \mathrm{cdef}$ & $154.0 \pm 10.7 \mathrm{abcdef}$ & $251.6 \pm 8.0 \mathrm{bcdef}$ \\
Elf & $86.4 \pm 5.8 \mathrm{cdef}$ & $140.5 \pm 15.5 \mathrm{cdef}$ & $227.2 \pm 16.7 \mathrm{defgh}$ \\
Firecracker & $68.3 \pm 1.2 \mathrm{hi}$ & $114.9 \pm 6.6 \mathrm{ghij}$ & $164.9 \pm 11.9 \mathrm{j}$ \\
Forever Red & $99.6 \pm 1.4 \mathrm{abc}$ & $146.4 \pm 16.6 \mathrm{abcdef}$ & $244.2 \pm 18.7 \mathrm{bcdefg}$ \\
Freckles & $105.3 \pm 3.8 \mathrm{a}$ & $160.2 \pm 7.0 \mathrm{abcd}$ & $232.1 \pm 19.9 \mathrm{cdefgh}$ \\
Heart of Fire & $100.7 \pm 5.4 \mathrm{ab}$ & $168.5 \pm 10.1 \mathrm{ab}$ & $275.3 \pm 7.5 \mathrm{ab}$ \\
Kaleidoscope & $78.9 \pm 2.6 \mathrm{efgh}$ & $110.2 \pm 4.7 \mathrm{hij}$ & $175.1 \pm 13.0 \mathrm{ij}$ \\
Little Linda & $88.4 \pm 4.0 \mathrm{bcde}$ & $135.5 \pm 4.7 \mathrm{defg}$ & $215.3 \pm 9.1 \mathrm{gh}$ \\
Minuet & $74.5 \pm 4.3 \mathrm{fghi}$ & $143.8 \pm 2.8 \mathrm{bcdef}$ & $156.1 \pm 5.3 \mathrm{j}$ \\
Nathan Hale & $62.3 \pm 2.3 \mathrm{i}$ & $96.8 \pm 7.0 \mathrm{j}$ & $213.6 \pm 4.6 \mathrm{gh}$ \\
Olympic Fire & $99.4 \pm 6.9 \mathrm{abc}$ & $171.1 \pm 5.2 \mathrm{a}$ & $264.8 \pm 14.2 \mathrm{bc}$ \\
Ostbo Red & $101.6 \pm 3.4 \mathrm{ab}$ & $149.5 \pm 6.9 \mathrm{abcdef}$ & $253.5 \pm 4.0 \mathrm{bcde}$ \\
Peppermint & $97.0 \pm 4.2 \mathrm{abcd}$ & $157.4 \pm 7.2 \mathrm{abcde}$ & $270.5 \pm 15.7 \mathrm{ab}$ \\
Pink Charm & $105.9 \pm 7.4 \mathrm{a}$ & $164.2 \pm 8.6 \mathrm{abc}$ & $229.9 \pm 2.3 \mathrm{cdefgh}$ \\
Pristine & $89.5 \pm 5.8 \mathrm{bcde}$ & $105.3 \pm 3.5 \mathrm{ij}$ & $255.8 \pm 15.2 \mathrm{bcd}$ \\
Red Bandit & $89.9 \pm 5.0 \mathrm{bcde}$ & $140.0 \pm 8.3 \mathrm{cdefg}$ & $218.5 \pm 6.2 \mathrm{efgh}$ \\
Sarah & $91.9 \pm 2.9 \mathrm{bcde}$ & $129.2 \pm 12.3 \mathrm{fghi}$ & $201.1 \pm 14.2 \mathrm{hi}$ \\
Snowdrift & $85.7 \pm 3.5 \mathrm{def}$ & $98.7 \pm 4.9 \mathrm{j}$ & $221.2 \pm 17.8 \mathrm{defgh}$ \\
Starburst & $81.7 \pm 3.5 \mathrm{efg}$ & $103.7 \pm 8.5 \mathrm{j}$ & $216.6 \pm 22.0 \mathrm{fgh}$ \\
Tinkerbell & $71.2 \pm 2.4 \mathrm{ghi}$ & $134.1 \pm 5.9 \mathrm{efgh}$ & $169.9 \pm 10.7 \mathrm{ij}$ \\
\hline Gowh & &
\end{tabular}

${ }^{\mathrm{z}}$ Growth index was calculated as height + width $1+$ width 2 . Width 1 and width 2 measured perpendicular to each other with width $l$ at the widest point; $1 \mathrm{~cm}=0.3937$ inch.

${ }^{\mathrm{y}}$ Measurements were taken before plants were transplanted to 3 -gal $(11.4 \mathrm{~L})$ containers in 2015 .

x Data followed by different letters within the column mean they were significantly different at $P<0.05$ according to Fisher's least significant difference.

growth indices in $2015(\geq 145 \mathrm{~cm})$ and $2017(\geq 230 \mathrm{~cm})$, despite having smaller size in 2014 compared with 'Bullseye', 'Forever Red', 'Freckles', 'Heart of Fire', 'Olympic Fire', 'Ostbo Red', and 'Pink Charm'. On the basis of these results, nine mountain laurel cultivars including Bullseye,
Carol, Forever Red, Freckles, Heart of Fire, Olympic Fire, Ostbo Red, Peppermint, and Pink Charm would be good candidates for production in 1gal containers and could be sold after a single year in production. Transplanting these cultivars in the second year from 1- to 3-gal containers and 
selling them as 3 -gal containers is also an option for growers. Although this increases input(s), labor, facility, and shipping resources, the fast growth rate of these cultivars and higher prices of 3-gal containers may compensate for additional inputs.

In contrast, 'Firecracker', 'Kaleidoscope', 'Minuet', 'Nathan Hale', and 'Tinkerbell' yielded less than 80 $\mathrm{cm}$ of total growth in 2014 (Table 3 ). 'Firecracker' and 'Kaleidoscope' were considered to be dense/compact growers and accordingly had smaller growth indices of $<115$ and $180 \mathrm{~cm}$ in 2015 and 2017 , respectively. Interestingly, two cultivars frequently marketed as dwarf, Minuet and Tinkerbell, had greater growth indices in 2015 when compared with Firecracker and Kaleidoscope. Three cultivars marketed as dwarf spreading cultivars including Elf, Little Linda, and Starburst and four nondwarf cultivars including Pristine, Red Bandit, Sarah, and Snowdrift displayed moderate growth throughout the 4-year container evaluation. These slow and moderate growers could also reach a salable size in a 1 -gal container in 1 year. An additional 2 years would be required to reach a salable size in a 3gal container as defined by a growth index of $150 \mathrm{~cm}$ that is common among plants at the time of sale.

'Elf', 'Freckles', and 'Goodrich' were trialed in container production at Griffin, GA, and Puyallup, WA. by Hummel et al. (1990). Rooted liners of 'Elf' and 'Freckles' yielded more than $25 \mathrm{~cm}$ of growth index (height + width/2) in 6 months of production at both locations, with 'Freckles' having overall greater size than 'Elf'. This corroborates our results, in that 'Freckles' was a fast grower while 'Elf' had moderate size throughout the evaluation period. Because limited studies have been conducted to quantify the growth of containergrown mountain laurel, container trial results from this study provide novel detailed growth information for the 21 cultivars tested.

Morphology. The 21 mountain laurel cultivars trialed in this study were subjected to morphological analysis of 11 phenotypic traits (Table 1). PCA indicated that the first four components accounted for $30.07 \%, 21.65 \%, 13.08 \%$, and $11.08 \%$ of the morphological variance respectively, their cumulative variance being $75.88 \%$ (Table 4 ). On the basis of eigenvector values for traits along the first two components, the major traits responsible for morphological diversity were flower size, bud color, and habit along the first component (PCl). Leaf color, leaf size, and leaf blade fell along the second component (PC2). The first two components were used to visualize a scatter plot whereby cultivars were divided into five groups (Fig. 2). The first group (group 1) consisted of 10 cultivars including Bullseye, Carol, Firecracker, Forever Red, Heart of Fire, Nathan Hale, Olympic Fire, Ostbo Red, Pink Charm, and Sarah that had higher PCl values. These cultivars had typical (nondwarf) habit and deep pink to red flower buds. Six cultivars including Freckles, Kaleidoscope, Little Linda, Peppermint, Red Bandit, and Tinkerbell having PCl value near 0 , were classified into two

Table 4. Eigenvectors and eigenvalues generated by principal component analysis (PCA) applied on 11 morphological characteristics of 21 mountain laurel cultivars.

\begin{tabular}{lrrrr}
\hline & \multicolumn{4}{c}{ Eigenvectors } \\
\cline { 2 - 5 } Variable & PC1 & \multicolumn{1}{c}{ PC2 } & \multicolumn{1}{c}{ PC3 } & PC4 \\
\hline Habit & 0.626 & -0.650 & 0.044 & 0.032 \\
Stem and petiole color & 0.599 & 0.324 & 0.517 & -0.055 \\
Leaf size & 0.573 & -0.617 & 0.026 & 0.416 \\
Leaf blade & 0.262 & -0.604 & 0.251 & -0.470 \\
Leaf surface & 0.580 & 0.148 & -0.654 & 0.156 \\
Leaf color & 0.288 & 0.783 & 0.284 & 0.284 \\
Flower size & 0.823 & -0.264 & -0.007 & 0.133 \\
Bud color & 0.807 & 0.431 & -0.034 & 0.056 \\
Corolla color & 0.485 & 0.286 & 0.374 & -0.541 \\
Pigment pattern & -0.277 & -0.124 & 0.585 & 0.633 \\
Blooming time & 0.315 & 0.348 & -0.337 & 0.028 \\
Eigenvalues & & & & \\
Eigenvalue & 3.308 & 2.381 & 1.439 & 1.219 \\
Percent of total variance & 30.070 & 21.650 & 13.081 & 11.078 \\
$\quad$ explained & & & & 75.879 \\
Cumulative percent of total & 30.070 & 51.720 & 64.800 & \\
$\quad$ variance explained & & & & \\
\hline
\end{tabular}

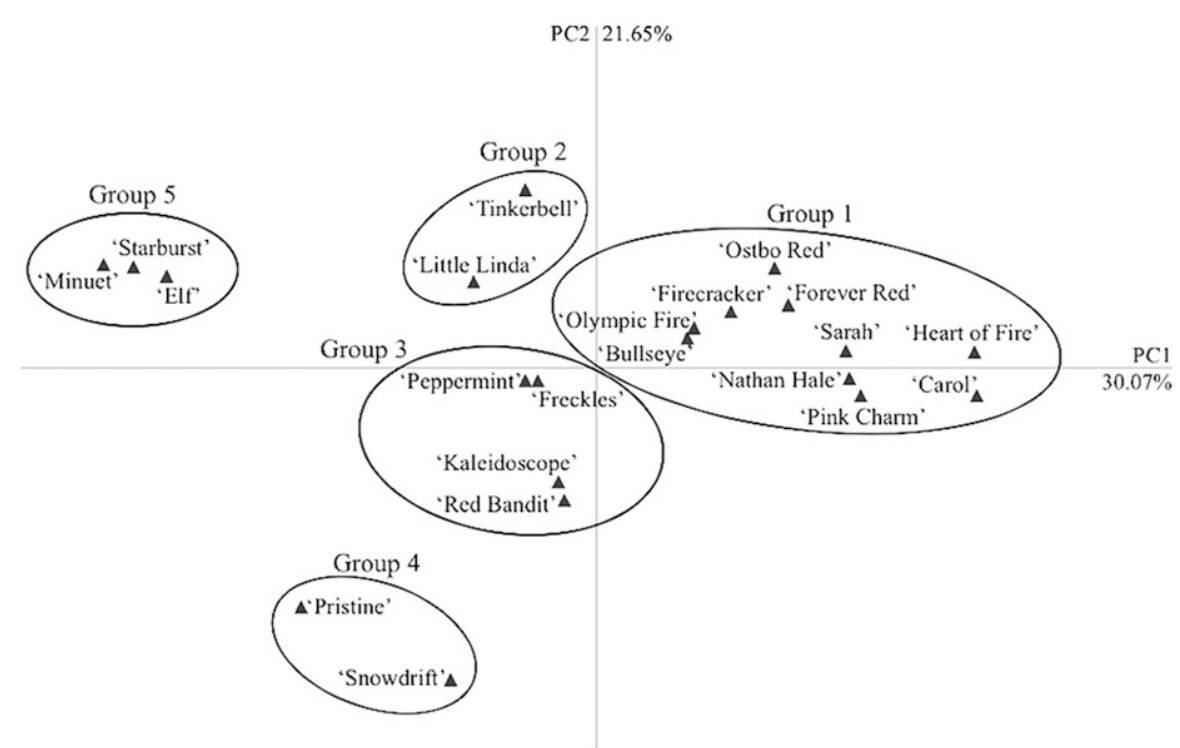

Fig. 2. Scatter plot of 21 mountain laurel cultivars obtained performing principal component analysis (PCA) on 11 morphological characteristics related to habit, stem, leaf, and flower. PC1 and PC2 explain 30.07\% and $21.65 \%$ of morphological variation, respectively, with cumulative variance being $51.72 \%$. Twenty-one cultivars were classified into five phenotypic groups based on PC1 and PC2 values. 
groups based on their different PC2 values. The first group (group 2) contained two dwarf cultivars, Little Linda and Tinkerbell, that had Vshaped foliage and pink flowers, whereas the second group (group 3) comprised four nondwarf cultivars including Freckles, Kaleidoscope, Peppermint, and Red Bandit that had pigmented (in spot or band pattern) pink flowers. Cultivars Pristine and Snowdrift comprised group 4, separated from other cultivars by low PC2 values. These two cultivars displayed medium green stem and foliage and pure white inflorescence that were very distinctive. Three dwarf cultivars, Elf, Minuet, and Starburst, comprised group 5, based on low $\mathrm{PCl}$ values. These three cultivars had more dense habit and lighter pink buds compared with Little Linda and Tinkerbell. The results confirmed visual observations, in that mountain laurel cultivars have a wide range of morphological combinations. Yet, PCA also indicated sharing of traits among five distinct groups. This classification information should provide plant breeders with useful information that affords insight into breeding for optimal growth index combined with favorable phenotypic characteristics. Additionally, growers in the southeastern United States could use this information to select cultivars having optimal growth indices from each of five groups. This would afford growers the ability to select fast-growing cultivars while maximizing phenotypic diversity in a minimum number of cultivars.

LEAF SPOT INCIDENCE. The majority of cultivars selected for this study were reported as leaf spot tolerant in the northeastern United States. No leaf spot was observed on cultivars Ostbo Red, Pristine, and Tinkerbell, whereas all other cultivars in this study had observed leaf spot incidence. Similarly, Jaynes (1988) observed that 'Ostbo Red' and 'Tinkerbell' showed higher tolerance to leaf spot compared with other cultivars. 'Pristine' was selected from a seed-lot collected in a wild population growing within $30 \mathrm{~km}$ of Woodlander Nursery [Aiken, SC, USDA Zone 8a (USDA, 2012)]. This is one of few cultivars on the market that was introduced from a selection program in the southeastern United States. As a result of continual disease pressure observed in the southeastern United States and the fact that 'Pristine' was selected from a native population in the region that evolved in these conditions, 'Pristine' is more likely to have higher level of tolerance to leaf spot. Similar results were obtained in leaf spot tolerance studies in rabbiteye blueberry (Vaccinium ashei) selections that were derived from genotypes developed and/or selected from wild types in the southeastern United States. In the case of rabbiteye blueberry, leaf spot tolerance was tied to greater adaptability of genotypes derived from southeastern U.S. germplasm that were subjected to hot and humid conditions of the southeastern United States, compared with northern highbush blueberry [Vaccinium corymbosum (Scherm, 2008)].

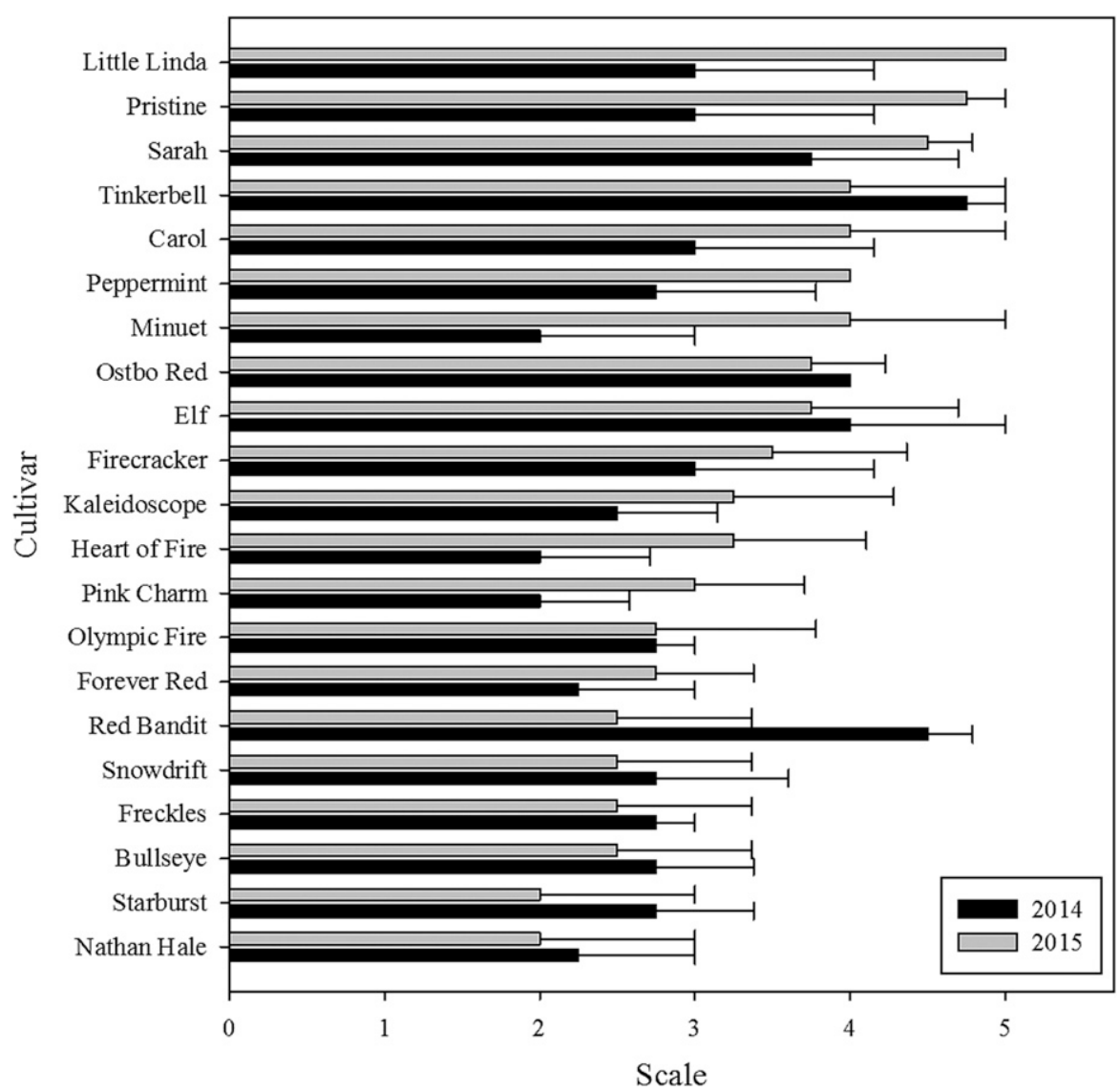

Fig. 3. Field performance rating of 21 mountain laurel cultivars at the University of Georgia Durham Horticulture Farm in Watkinsville, GA, after the 2014 growing season (black bar) and 2015 growing season (gray bar). Plants were evaluated using a scale of 1 (dead) to 5 (excellent) and the rating was based on overall plant size and vigor, leaf color, incidence of leaf spot, and abiotic leaf and shoot damage. Data are presented as mean $\pm \operatorname{SE}(n=4)$ by the descending order of ranking in 2015. Different letters indicate that performance ratings of cultivars in 2014 are significantly different at $P<0.05$ according to Fisher's least significant difference. 
cultivars in year 2 indicated mountain laurel could have enhanced performance in landscapes after establishment (observed in year 2) and adapt to local southeastern U.S. conditions (high heat and humidity). On the basis of the rating results from 2014 and 2015 , the 10 highest rated cultivars (Carol, Elf, Firecracker, Little Linda, Minuet, Ostbo Red, Peppermint, Pristine, Sarah, and Tinkerbell) were subsequently evaluated for field performance at the UGA Riverbend Research Center in 2016.

There was no significant difference in performance rating among the 10 cultivars field-trialed in 2016 (Table 2). Performance ratings in 2016 ranged from 1.0 to 3.3 , lower than the initial field trial in 2014-15 (Table 5). 'Elf' received consistently high ratings after the initial field trial in 2014 (4.0) and 2015 (3.8), yet its performance rating dropped to 1.8 in 2016 (Table 5; Fig. 3). This reduction in performance rating could be due to transplant date. The initial field trial, conducted in 2014-15, was planted in Fall 2013 (1 Oct. 2013). Hanson et al. (2004) reported the main difficulty in establishing container-grown mountain laurel plants in landscapes was the lack of root extension into backfill-soil after transplanting in spring. Fall planting, as observed in the first field study conducted in 2014-15, was proceeded

Table 5. Field performance rating, net growth, and percentage of decrease in maximum quantum yield of photosystem II $\left(\mathrm{F}_{\mathrm{v}} / \mathrm{F}_{\mathrm{m}}\right)$ of 10 mountain laurel cultivars at the University of Georgia Riverbend Research Center at Athens, GA, in $2016(n=4)$.

\begin{tabular}{lccc}
\hline & Rating $(\mathbf{1}-\mathbf{5} \text { scale })^{\mathrm{z}}$ & Net growth $(\mathbf{c m})^{\mathrm{y}}$ & Decrease in $\mathrm{F}_{\mathbf{v}} / \mathrm{F}_{\mathbf{m}}(\mathbf{\%})^{\mathrm{x}}$ \\
\cline { 2 - 4 } Cultivar & \multicolumn{3}{c}{$($ mean $\pm \mathrm{SE})$} \\
\hline Ostbo Red & $2.5 \pm 0.7$ & $58.7 \pm 11.7 \mathrm{a}$ & $43.8 \pm 33.0$ \\
Peppermint & $1.5 \pm 0.5$ & $55.6 \pm 10.6 \mathrm{ab}$ & $73.8 \pm 26.2$ \\
Tinkerbell & $3.3 \pm 1.0$ & $54.8 \pm 13.9 \mathrm{ab}$ & $49.8 \pm 29.0$ \\
Little Linda & $1.8 \pm 0.8$ & $49.0 \pm 4.6 \mathrm{abc}$ & $75.3 \pm 24.7$ \\
Firecracker & $1.0 \pm 0.0$ & $43.6 \pm 1.5 \mathrm{abc}$ & $100.0 \pm 0.0$ \\
Minuet & $1.5 \pm 0.5$ & $40.5 \pm 17.0 \mathrm{abc}$ & $75.9 \pm 24.1$ \\
Sarah & $1.0 \pm 0.0$ & $39.4 \pm 7.5 \mathrm{abc}$ & $100.0 \pm 0.0$ \\
Pristine & $2.8 \pm 1.0$ & $35.3 \pm 4.1 \mathrm{abc}$ & $50.9 \pm 29.0$ \\
Elf & $1.8 \pm 0.8$ & $32.7 \pm 5.9 \mathrm{bc}$ & $72.8 \pm 27.2$ \\
Carol & $2.0 \pm 1.0$ & $28.9 \pm 16.0 \mathrm{c}$ & $74.4 \pm 25.6$ \\
\hline
\end{tabular}

${ }^{\mathrm{z}}$ Field performance rating was evaluated using a scale of 1 (dead) to 5 (excellent) and the rating was based on overall plant size and vigor, leaf color, incidence of leaf spot, and leaf and shoot abiotic damage.

${ }^{y}$ Growth index was calculated as height + width $1+$ width 2 . Width 1 and width 2 measured perpendicular to each other with width 1 at the widest point. Net growth was calculated as final growth index-initial growth index; $1 \mathrm{~cm}=$ 0.3937 inch.

${ }^{\mathrm{x}}$ Initial and final $\mathrm{F}_{\mathrm{v}} / \mathrm{F}_{\mathrm{m}}$ were measured on plants before being planted to the field and after growing season, respectively. The percentage of decrease in $\mathrm{F}_{\mathrm{v}} / \mathrm{F}_{\mathrm{m}}$ was then calculated as $\left[\left(\right.\right.$ initial $\mathrm{F}_{\mathrm{v}} / \mathrm{F}_{\mathrm{m}}-$ final $\left.\mathrm{F}_{\mathrm{v}} / \mathrm{F}_{\mathrm{m}}\right) /$ initial $\left.\mathrm{F}_{\mathrm{v}} / \mathrm{F}_{\mathrm{m}} \times 100 \%\right]$.

wData are sorted by descending numerical values of net growth. Data followed by different letters within the column indicate differences in mean values at $P<0.05$ according to Fisher's least significant difference.
0.78 to 0.84 , whereas all cultivars showed decreased $\mathrm{F}_{\mathrm{v}} / \mathrm{F}_{\mathrm{m}}(0.00$ to $0.80)$ at the conclusion of field trials. Decrease in $\mathrm{F}_{\mathrm{v}} / \mathrm{F}_{\mathrm{m}}$ was therefore used to compare the ability of mountain laurel cultivars to adapt to southeastern U.S. environmental conditions. In this scenario, a lower percentage decrease in $\mathrm{F}_{\mathrm{v}} / \mathrm{F}_{\mathrm{m}}$ indicated less damage of photosystem II and therefore enhanced stress tolerance. Negative correlation between percentage decrease in $\mathrm{F}_{\mathrm{v}} / \mathrm{F}_{\mathrm{m}}$ and performance rating was observed among all cultivars. 'Ostbo Red', 'Pristine', and 'Tinkerbell' had less decrease in $\mathrm{F}_{\mathrm{v}} / \mathrm{F}_{\mathrm{m}}(<5 \mathrm{l} \%)$, whereas other cultivars had greater decrease in $\mathrm{F}_{\mathrm{v}} / \mathrm{F}_{\mathrm{m}}(>70 \%)$ (Table 5). When combined with performance ratings, $F_{v} / F_{m}$ appeared to be a parameter that could reflect stress tolerance of mountain laurel cultivars.

\section{Conclusion}

Twenty-one mountain laurel cultivars displayed various responses to container and field trials when evaluated in the southeastern United States (USDA Zone 8a). Although the 21 cultivars displayed differing growth indices in container production, all cultivars could yield sufficient growth the first year after being transplanted into l-gal containers and consistently perform well thereafter in a container production environment. This indicated that growing mountain laurel for 1 year as l-gal container plant should be feasible for southeastern U.S. producers. Fastgrowing cultivars including Bullseye, Carol, Forever Red, Freckles, Heart of Fire, Olympic Fire, Ostbo Red, Peppermint, and Pink Charm could be shifted up to and finished in 3-gal containers. Additionally, mountain laurel cultivars had a variety of morphological characteristics and fell into five phenotypic (PCA) groups based on shared morphological traits when grown in a container production environment, principally on habit, foliage, and inflorescence traits. Results of this study should benefit plant breeders and commercial producers by providing regional cultivar information for the southeastern United States (and other USDA Zone 8-9 environments). 'Ostbo Red', Pristine', and 'Tinkerbell' would be recommended to the southeastern U.S. producers to have both phenotypic variability in the cultivars produced 
and leaf spot tolerance. Although most cultivars in this study had difficulty establishing in southeastern U.S. landscapes, fall planting could facilitate improved establishment. Three cultivars, Ostbo Red, Pristine, and Tinkerbell, consistently excelled in field trials, indicating that they are more adapted to landscape environmental conditions observed in the southeastern United States.

\section{Literature cited}

Baker, N.R. and E. Rosenquist. 2004. Applications of chlorophyll fluorescence can improve crop production strategies: An examination of future possibilities. J. Expt. Bot. 55:1607-1621.

Dirr, M.A. 2009. Manual of woody landscape plants. 6th ed. Stipes Publishing, Champaign, IL.

Givnish, T.J. 1984. Leaf and canopy adaptations in tropical forests, p. 51-84. In: E.H. Medina, A. Mooney, and C. Vasques-
Yanes (eds.). Physiological ecology of plants in the wet tropics. D. W. Junk Publ., The Hague, The Netherlands.

Hanson, A.M., J.R. Harris, and R. Wright. 2004. Effects of transplant season and container size on landscape establishment of Kalmia latifolia L. J. Environ. Hort. 22:133-138.

Hummel, R.L., C.R. Johnson, and O.M. Lindstrom. 1990. Root and shoot growth response of three container-grown $\mathrm{Kal}$ mia latifolia L. cultivars at two locations to growing medium and nitrogen form. J. Environ. Hort. 8:10-13.

Jaynes, R.A. 1982. New mountain laurel selections and their propagation. Intl. Plant Prop. Soc. Proc. 32:431-434.

Jaynes, R.A. 1988. Kalmia: The laurel book. Timber Press, Portland, OR.

Kalaji, H.M., R. Carpentier, S.I. Allakhverdiev, and K. Bosa. 2012. Fluorescence parameters as early indicators of light stress in barley. J. Photochem. Photobiol. B. 112:1-6.

Kurmes, E.A. 1967. The distribution of Kalmia latifolia L. Amer. Midl. Nat. 77:525-526.

Maxwell, K. and G.N. Johnson. 2000. Chlorophyll fluorescence-a practical guide. J. Expt. Bot. 51:659-668.

Scherm, H. 2008. Disease management in organic rabbiteye blueberries. Intl. J. Fruit Sci. 8:69-80.

Schlichting, C.D. 1986. The evolution of phenotypic plasticity in plants. Annu. Rev. Ecol. Syst. 17:667-693.

European Kalmia Society. 2018. Laurel cultivars-the international Kalmia register and checklist. 2 Oct. 2018. <http:// www.kalmia-society.org/cultivars.php? \&lang $=\mathrm{gb}>$.

U.S. Department of Agriculture (USDA). 2012. USDA plant hardiness zone map. 1 Aug. 2018. <http://planthardiness.ars. usda.gov/PHZMWeb $>$. 